Ilmu Pertanian (Agricultural Science)

Vol. 2 No. 1 April, 2017 : 015-019

Available online at http://journal.ugm.ac.id/jip

DOI: doi.org/10.22146/ipas.11194

\title{
Analysis of The Growth of Oil Palm (Elaeis guineensis Jacq.) Exposed by Aluminum Toxicity and Silica as an Amelioration
}

\author{
Satiti Ratnasari*, Eka Tarwaca Susila Putra, Didik Indradewa \\ Department of Agronomy, Faculty of Agriculture, Universitas Gadjah Mada \\ Jln. Flora no. 1, Bulaksumur, Sleman, Yogyakarta 5528, Indonesia \\ *Corresponding email: satiti.ratnasari@gmail.com
}

Received: $13^{\text {rd }}$ May 2016 ; Revised: $28^{\text {th }}$ June 2016 ; Accepted: $28^{\text {th }}$ August 2017

\begin{abstract}
Aluminum (Al) contained in acidic soil could become an obstacle for plant growth. The Al toxicity could inhibit root growth, water and nutrient absorption. One of the solution to overcome Al toxicity was by applying Silica (Si). The aim of this research was to study the impacts of Al to the growth activity of oil palm and to know the effects of Si to the growth activity of oil palm contaminated by Al. The factorial treatments were arranged in a complete random design with two factors. The first factor was Al toxicity, i.e. with and without Al, while the second factor was the application of Si that consisted of four levels (0, 32, 64, 96 gram per plant). some of variables included leaf area ratio (LAR), leaf area, net assimilation rate (NAR), relative growth ratio (RGR), plant height, and plant dry weight were observed. The result showed that Al toxicity decreased the LAR, leaf area, NAR, RGR, plant height, and plant dry weight. The application of Si 32 gram per plant increased leaf area ratio and was not significantly different from the application of 96 gram Si per plant. However, the application of Si to oil palm contaminated with Al did not affect to relative grow rate, but its application to normal plant would increase the relative growth ratio.
\end{abstract}

Keywords: Aluminum Toxicity, Oil Palm, Plant Growth, Silica

\section{INTRODUCTION}

In Indonesia, oil palm becomes a main commodity of plantation product and the biggest foreign exchange. The efforts to increase the production are done by plantation expansion and intensification. The expansion of oil palm plantation is done for lower productivity plantation, namely marginal land, but it is potentially to be regenerated via agronomic management. Indonesia has wide acidic soil area (Liao et al., 2006) which is also potential to be used as productive agricultural land, yet those lands contain Aluminum (Al) toxicity, nitrogen $(\mathrm{N})$, potassium $(\mathrm{K})$, calcium $(\mathrm{Ca})$, magnesium $(\mathrm{Mg})$, and other essential micro nutrients.

$\mathrm{Al}$ is an abundant metal on earth surface which can potentially decrease the productivity of crops in acidic soil (Panda and Matsumoto, 2007). The dominant $\mathrm{Al}$ in acidic soil inhibits root growth, damages the root tip cells (Ryan et al., 1993; Kochian, 1995; Brunner and Sperisen, 2013), the absorption of essential nutrients, and cell division (Marschner, 1992: Hanum et al., 2007). Inhibited cell division of plant is caused by the $\mathrm{Al}$ toxicity on the cell wall and it disrupts mitotic activity.

$\mathrm{Si}$ is known as the substance that can resolve abiotic and biotic toxicity (Meena et al., 2013). The application of Silica on soil can increase the availability of $\mathrm{P}$ and decrease the activity of toxic metal such as $\mathrm{Al}$ (Yukamgo and Yuwono, 2007). The mechanisms of $\mathrm{Si}$ in decreasing the effects of $\mathrm{Al}$ toxicity are a) Si induction can increase $\mathrm{Ph}$ solvent, b) reducing the availability aluminum, or c) as the detoxification in plant (Pontigo, 2015).

Growth is defined as a cell division (the increasing of cell amount) and cell enlargement (the increasing of cell size). This process requires synthesise of protein and an irreversible process. An approach towards the analysed factors affect crop yields and the analysis of plant development as net accumulation of photosynthesis is integrated to the time, or is called as growth analysis (Gardner et. al., 1991).

This research aimed to study the impacts of Al to the growth activity of oil palm; and to know the effects 
of Si to oil palm growth activity exposed by $\mathrm{Al}$ toxicity. This research was conducted using a simulation of oil palm in main nursery phase. Planting media as environment condition is adapted into mineral acid soil. The response of the grown oil palm toward $\mathrm{Al}$ toxicity is also represented in the response of the seed phase. The research aimed to identify the respone of Al toxicity and application of $\mathrm{Si}$ as amelioration to changing patterns of the oil palm growth.

\section{MATERIALS AND METHODS}

This research was conducted on February to June 2015 in Bendosari, Madurejo, Prambanan, Sleman, D.I Yogyakarta. The materials were main nursery phase of oil palm seed, NPK fertiliser, (15:15:15), regosol soil, Aluminum Sulphate with $\mathrm{Al}_{2} \mathrm{O}_{3}$ content $\geq$ $17 \%$ and silica fertiliser $\left(\mathrm{SiO}_{2} 30-32 \%\right)$. Polybag, hoe, ruler, oven, leaf area meter, and an analytical balance were used as tools. The experiment was arranged in a complete random design with two factors. The first factor was the $\mathrm{Al}$ toxicity exposure, with or without the application of $300 \mathrm{ppm} \mathrm{Al}$ toxicity. The second factor was the application of Si which consisted of four levels, i.e. 0, 32, 64, and 96 gram per plant. Si was applied to one month old of main nursery plant which had been moved from pre-nursery by sowing on circle line with diameter from the rod around $10 \mathrm{~cm}$, then buried with the soil. Al toxicity treatment was applied after one month by watering the oil palm seed everyday with Aluminum Sulphate solvent 300 ppm, volume 500 $\mathrm{mL}$ per day.

Some variables included leaf area ratio (LAR), leaf area, net assimilation rate (NAR), relative growth rate (RGR), height of plant, plant dry weight were observed in this research. The variable calculation formulas for LAR, NAR, and RGR were as follows:

a. Leaf Area Ratio (LAR)

$$
\mathrm{LAR}=\frac{L a}{W} \mathrm{dm}^{2} / \mathrm{g}
$$

b. Net Assimilation Growth (NAR)

$$
\begin{aligned}
& \mathrm{NAR}=\frac{W_{2}-W_{1}}{T_{2}-T_{1}} \times \frac{\ln l a_{2}-\ln l a_{1}}{l a_{2}-l a_{1}} \mathrm{~g} / \mathrm{dm}^{2} / \text { week } \\
& \text { c. Relative Growth Ratio (RGR) } \\
& \qquad \quad \mathrm{PGR}=\frac{\ln W_{2}-\ln W_{1}}{T_{2}-T_{1}} \mathrm{~g} / \mathrm{g} / \mathrm{wwk}
\end{aligned}
$$

Note: $\mathrm{La}=$ leaf area, $\mathrm{T}=$ age of seedlings, $\mathrm{W}=$ plant dry weight, $1,2=1^{\text {st }}$ taken sample (taken one month after the treatment of Al) and $2^{\text {nd }}$ taken sample (taken when the plants show the signs of being exposed of Al).

The plant height was measured by ruler and leaf area was measured by leaf area meter. For measuring dry weight, sample was dried in the oven at $65^{\circ} \mathrm{C}$ until it reached a constant weight. The plant height was measured once a week, whereas leaf area and dry weight were measured after oil palm was exposed to Al toxicity. The obtained data were analysed using analysis of variance (ANOVA) at $5 \%$ of significant level, and if the result of the analysis showed a significant difference between treatments, the analysis was continued using Duncan (DMRT).

\section{RESULT AND DISCUSSION}

Based on the analysis of variance, the Al toxicity and the application of Si did not showed significant differences (Table 1). Aluminum toxicity 300 ppm decreased leaf area ratio (LAR) of oil palm for $44.60 \mathrm{dm}^{2} \mathrm{~g}^{-1}$. Application of 32 gram per plant Si increased LAR, but the result was not different compared with the application of 96 gram Si per plant. LAR described the plant ability to form leaves.

Leaves were important organ of plant growth. In leaves, chlorophyll pigments used to help the process of photosynthesis. Ai (2012) mentioned that photosynthesis was a process of carbohydrate synthesis from inorganic materials $\left(\mathrm{CO}_{2}\right.$ and $\left.\mathrm{H}_{2} \mathrm{O}\right)$ by the help of the sun light on pigmentplant. The result of the photosynthesis process was carbohydrate which was used to produce energy for plants. The energy produced by photosynthesis process would help the growth activity and plant development.

Leaf area was an indicator for growth activity in oil palm. Larger leaves absorbed light better than narrow leaves. The more oil palm leaves could absorbed the sun light, the faster photosynthesis process could happen (Gardner, 1991). Table 2 provided information about the decreasing in leaf area caused by Al toxicity $\left(4095.74 \mathrm{dm}^{2}\right)$ and the application of Si did not affect leaf area.

Al toxicity inhibited root growth and the absorption of nutrients and water by plants (Marschner, 2012). Aluminum contained in plant inhibited root growth,

\begin{tabular}{|c|c|c|c|c|c|}
\hline \multirow{2}{*}{ Treatment } & \multicolumn{4}{|c|}{ Silica (gram/plant) } & \multirow{2}{*}{ Mean } \\
\hline & 0 & 32 & 64 & 96 & \\
\hline Without & 45.91 & 65.36 & 48.96 & 57.38 & $54.40 \mathrm{p}$ \\
\hline Al 300 ppm & 41.27 & 48.45 & 43.27 & 45.40 & $44.60 \mathrm{q}$ \\
\hline Mean & \multicolumn{5}{|c|}{43.59 b 56.91 a 46.11 b 51.39 ab (-) } \\
\hline
\end{tabular}

Table 1. Leaf Area Ratio $\left(\mathrm{dm}^{2} \mathrm{~g}^{-1}\right)$ of oil palm with and without $\mathrm{Al}$ toxicity exposure and the application of silica 
Table 2. Leaf Area $\left(\mathrm{dm}^{2}\right)$ of oil palm with and without $\mathrm{Al}$ toxicity exposure and the application of silica

\begin{tabular}{|c|c|c|c|c|c|}
\hline \multirow{2}{*}{ Treatment } & \multicolumn{4}{|c|}{ Silica (gram/plant) } & \multirow{2}{*}{ Mean } \\
\hline & 0 & 32 & 64 & 96 & \\
\hline Without & 7416.80 & 7022.55 & 7212.38 & 7108.82 & $7190.14 p$ \\
\hline Al 300 ppm & 4240.37 & 3411.23 & 4161.62 & 4569.75 & $4095.74 \mathrm{q}$ \\
\hline Mean & $5828.58 \mathrm{a}$ & $5216.89 \mathrm{a}$ & $5687.00 \mathrm{a}$ & $5839.28 \mathrm{a}$ & $(-)$ \\
\hline
\end{tabular}

Table 3. Net Assimilation Rate $\left(\mathrm{mg} \mathrm{dm}^{-2}\right.$ day $\left.^{-1}\right)$ of oil palm with and without $\mathrm{Al}$ toxicity exposure and the application of silica

\begin{tabular}{|c|c|c|c|c|c|}
\hline \multirow{2}{*}{ Treatment } & \multicolumn{4}{|c|}{ Silica (gram/plant) } & \multirow{2}{*}{ Mean } \\
\hline & 0 & 32 & 64 & 96 & \\
\hline Without & 0.0012 & 0.0022 & 0.0018 & 0.0023 & $0.0018 \mathrm{p}$ \\
\hline Al 300 ppm & 0.0013 & 0.0009 & 0.0009 & 0.0011 & $0.0010 \mathrm{q}$ \\
\hline Mean & $0.0012 \mathrm{a}$ & $0.0015 \mathrm{a}$ & $0.0013 \mathrm{a}$ & $0.0017 \mathrm{a}$ & $(-)$ \\
\hline
\end{tabular}

Table 4. Relative Growth Ratio $\left(\mathrm{mg} \mathrm{g}^{-1}\right.$ day $\left.^{-1}\right)$ of oil palm with and without Al toxicity exposure and the application of silica

\begin{tabular}{lccccc}
\hline \multirow{2}{*}{ Treatment } & \multicolumn{5}{c}{ Silica gram/plant) } \\
\cline { 2 - 5 } & 0 & 32 & 64 & 96 & \\
\hline Without & $0.0611 \mathrm{bc}$ & $0.1195 \mathrm{a}$ & $0.0852 \mathrm{ab}$ & $0.1196 \mathrm{a}$ & 0.0964 \\
Al 300 ppm & $0.0610 \mathrm{bc}$ & $0.0425 \mathrm{c}$ & $0.0401 \mathrm{c}$ & $0.0546 \mathrm{bc}$ & 0.0496 \\
\hline Mean & 0.0611 & 0.0810 & 0.0627 & 0.0871 & $(+)$ \\
\hline
\end{tabular}

Remarks: The numbers followed by the same letter in the column and row were not significantly different according to DMRT $\alpha 0.05$, (-) no interaction was found between treatments

caused alteration to root cells, plasma membrane, unbalance nutrients, callus accumulation, hemeostastic disruption of $\mathrm{Ca}^{2+}$ in the cytoplasm, and the production of Reactive Oxygen Species (ROS) (Silva, 2012). Gergichevich et al. (2010) stated that Al toxicity caused an increase in ROS synthesise which led to an oxidative stress. Oxidative stress could disrupt root, chloroplasts, and photosynthesis process. The disruption of root growth was followed by the inhibition of nutrient and water absorption, which led to a nutrient deficiency. Long term nutrient deficiency inhibited leaf growth and caused smaller and shrinking leaves.

A1 toxicity (300 ppm) could decrease the net assimilation rate (NAR) for $0.001 \mathrm{mg} \mathrm{dm}^{-2} \mathrm{day}^{-1}$, whereas the application of Si did not affect net assimilation rate (Table 3 ). Based on Table 4, an interaction was found between Al toxicity and the application of $\mathrm{Si}$. Al toxicity caused a decrease in relative growth rate (RGR). The application of $\mathrm{Si}$ did not affect oil palms exposed to Al toxicity, but the application of Si to normal oil palms (control plants) could increase the relative growth rate (RGR). The decreasing of leaf area ratio (LAR) was followed by the decreasing of LAB $(r=0.55)$ and RGR ( $r=0.70)$.

RGR was the plant ability to produce dry materials from the assimilation result per unit area per unit time. The analysis result showed a positive correlation between NAR and RGR ( $r=0.97)$. The increasing NAR for a long term was followed by the increasing of RGR, and so forth. NAR also showed a positive correlation with leaf area $(r=0.68)$ and plant dry weight $(r=0.78)$. The increasing of leaf area was also followed by the increasing of NAR, which then brought the plant growth and development of oil palm. So it would increase the production of dry material which was indicated by the increasing of plant dry weight.

Figure 1 showed that in $13^{\text {th }}$ week observation, the plant height of oil palm which not exposed by Al toxicity was higher $(113.10 \mathrm{~cm})$ than oil palm plant which exposed by Al toxicity $(94.70 \mathrm{~cm})$.

Figure 2 showed the plant height from control (without Si application) was higher than the plant 


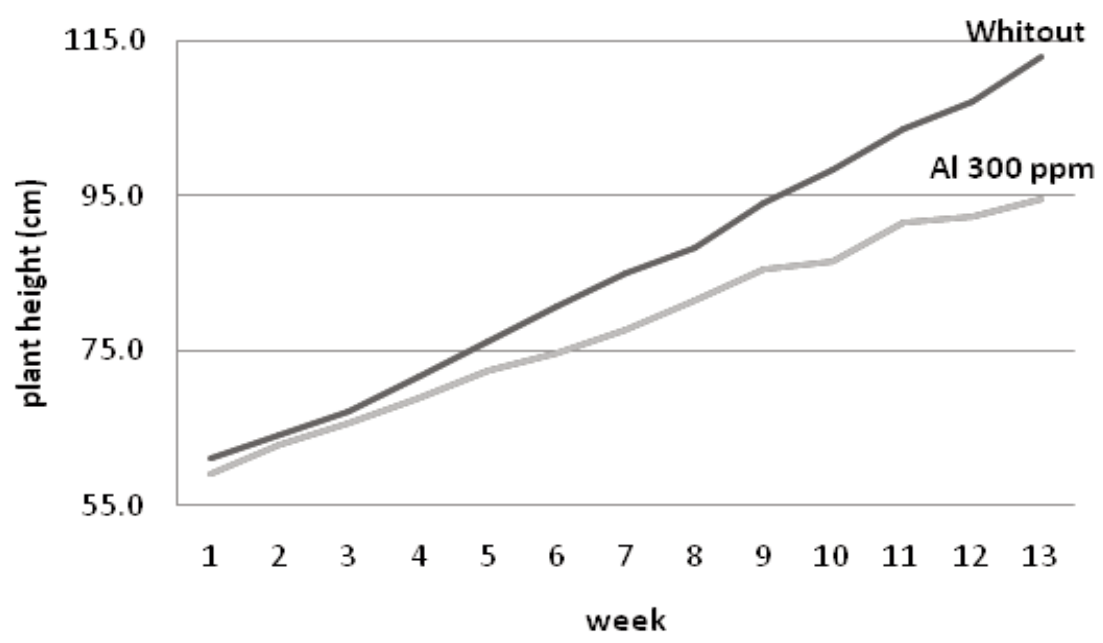

Figure 1. Plant height $(\mathrm{cm})$ of oil palm with the application of Si.

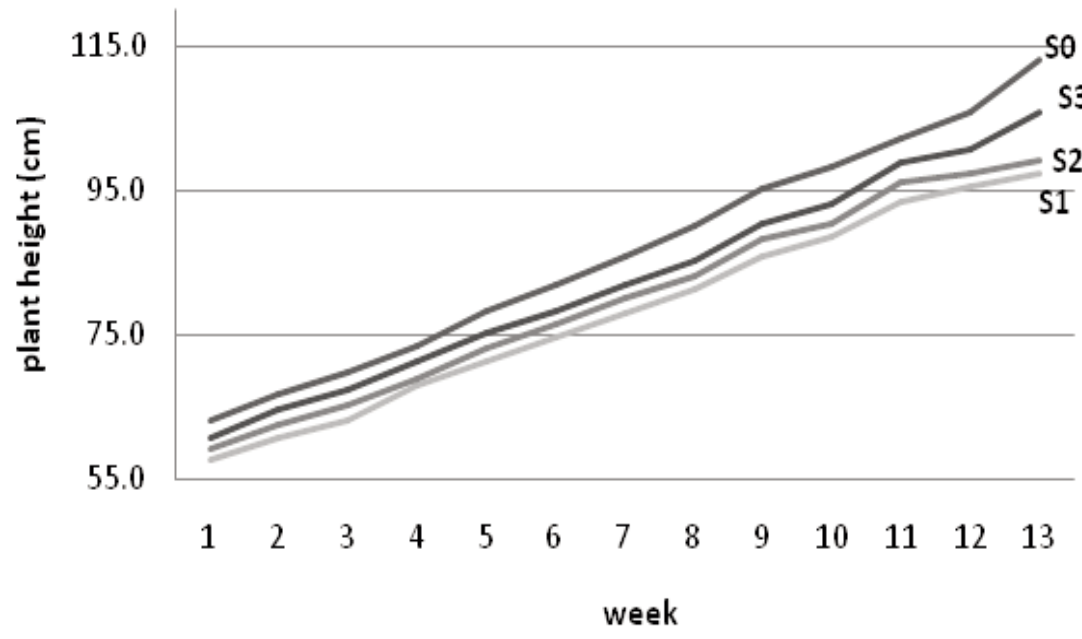

Remarks: S0 : 0 gram/plant, S1 : 32 gram/plant, S2 : 64 gram/plant, S3 : 96 gram/plant.

Figure 2. Plant height $(\mathrm{cm})$ of oil palm with the application of Si.

with application of 32 gram Si/plant. In the $13^{\text {th }}$ week observation, oil palm without application of Si fertiliser reached $113.1 \mathrm{~cm}$ in height, whereas oil palm with the application of 32 gram per plant $\mathrm{Si}$ fertiliser reached $97.4 \mathrm{~cm}$ in height. Based on analysis of variance, plant height showed an inhibitation after it was exposed to Al toxicity, yet the application of Si did not affect the plant height (Table 5.).

The correlation analysis result showed that leaf area had positive correlation with plant height $(\mathrm{r}=0.83)$ and plant dry weight $(\mathrm{r}=0.79)$. The increase in leaf area causedan increase in plant dry weight. High plant dry weight contained good assimilates which helped substrate cellular respiration. Sufficient amount of assimilates could boost maximum respiration in meristematic cells, then cells in meristematic zone would increase and grow bigger, so that they affected the plant growth. In addition, the increasing in oil palm leaf area could also increase the dry weight and plant height.

Plant dry weight illustrated the accumulation of organic compounds which were synthesised from
Table 5. Plant height $(\mathrm{cm})$ of oil palm with and without Al toxicity exposure and the application of silica

\begin{tabular}{llllll}
\hline \multirow{2}{*}{ Treatment } & \multicolumn{4}{c}{ Silica (gram/plant) } \\
\cline { 2 - 5 } Mean
\end{tabular}

\begin{tabular}{lccccc}
\hline Without & 123.83 & 106.98 & 109.13 & 112.34 & $113.07 \mathrm{p}$ \\
Al 300 ppm & 102.42 & 87.90 & 89.34 & 98.99 & $94.66 \mathrm{q}$ \\
\hline Mean & 113.13 a 97.44 a 99.23 a & 105.67 a & $(-)$ \\
\hline $\begin{array}{l}\text { Remarks: The numbers followed by the same letter in the column } \\
\text { and row were not significantly different according to }\end{array}$ \\
$\begin{array}{l}\text { DMRT } \alpha 0.05,(-) \text { no interaction was found between } \\
\text { treatments }\end{array}$
\end{tabular}

inorganic compounds by oil palm (Lakitan, 1993). The dry weight was formed from assimilation process of $\mathrm{CO}_{2}$ during plant growth (Gardner, 1991). Al toxicity made the plant dry weight lower to 80.91 gram (Table 6). This result was consistent with the research conducted by Baligar and Fageria (2005) in cocoa plant that showed the increasing of Al toxicity saturation impacted on the decreasing of dry weight and root, plant height, root length, relative growth ratio, and net assimilation rate.

There was a correlation found in leaf area, NAR, 
Table 6. Dry Weight (g) of oil palm with and without Al toxicity exposure and the application of silica.

\begin{tabular}{lccccc}
\hline \multirow{2}{*}{ Treatment } & \multicolumn{4}{c}{ Silica Dosage (gram/plant) } & \multirow{2}{*}{ Mean } \\
\cline { 2 - 5 } & 0 & 32 & 64 & 96 & \\
\hline Without & 131.21 & 146.455 & 144.971 & 140.046 & $140.67 \mathrm{p}$ \\
$\mathrm{Al} 300 \mathrm{ppm}$ & 81.1767 & 68.9663 & 85.1543 & 88.3621 & $80.91 \mathrm{q}$ \\
\hline Mean & $106.19 \mathrm{a}$ & $107.71 \mathrm{a}$ & $115.06 \mathrm{a}$ & $114.20 \mathrm{a}$ & $(-)$ \\
\hline Remarks: The numbers followed by the same letter in the column and row were \\
\\
$\begin{array}{l}\text { not significantly different according to DMRT } \alpha \\
\text { was found between treatments }\end{array}$
\end{tabular}

RGR, plant height, and plant dry weight with correlation coefficient were $0.68,0.68,0.82$, and 0.94 , respectively. The decreasing of leaf area (Table 1), NAR (Table 3), RGR (Table 4), and plant height (Table 5) of oil palm which were exposed to Al toxicity, followed by the decreasing of plant dry weight (Table 6).

\section{CONCLUSION}

Al toxicity decreased the growth activity of oil palm, indicated by the decreasing of leaf area, LAR, NAR, RGR, plant height, and plant dry weight. The application of Si did not decrease the effect of Al toxicity and ratio variable of leaf. The application of 32 gram per plant Si increased the ratio of leaf area, but was not significant different with the application of 96 gram Si per plant. However, the application of $\mathrm{Si}$ to oil palm which contaminated by Al did not affect to relative grow rate, but its application to normal plant would increase the relative growth ratio.

\section{REFERENCES}

Ai, N. S. 2012. Evolusi Fotosintesis Pada Tumbuhan. Jurnal Ilmiah Sains, 12: 28-34.

Badan Pusat Statistik. 2013. Direktori Perusahaan Perkebunan Kelapa Sawit. Jakarta: Badan Pusat Statistik.

Baligar, V. C. and N. K. Fageria. 2005. Soil Aluminium Effects on Growth and Nutrition of Cacao. Soil Science Plant Nutrition, 51: 709-713.

Brunner, I. and C. Sperisen. 2013. Aluminium exclusion and Aluminium Tolerance in woody Plants. Frontiers in Plant Science, 4: 1-12.

Gardner, F. P, R. B. Pearce, and R. L. Mitchell. 1991. Fisiologi Tanaman Budidaya. Jakarta: Penerbit Universitas Indonesia.

Gergichevich, C. M., M. Alberdi, A. G. Ivanov, and M. Reyes-Diaz. 2010. $\mathrm{Al}^{3+}-\mathrm{Ca}^{2+}$ Interaction in Plant Growing in Acid Soils: Al-Phytotoxicity Response to Calcareous Amendments. J. soil. Sci. plant nutr., 10: 217-243.

Hanum, C., W. Q. Mugnisjah, S. Yahya, D. Supandy, K. Idris dan A. Sahar. 2007. Petumbuhan Akar Kedelai pada Cekaman Alumunium, Kekeringan dan Cekaman Ganda Alumunium dan Kekeringan. Agritrop, 26: 13-18.

Kochian, L. V. 1995.Cellular Mechanisms of Aluminium Toxicity and Resistance in Plants. Annu. Rev. of Plant Physiol. and Plant Mol. Biol., 46: 237-260.

Lakitan, B. 1993. Dasar-dasar Fisiologi Tumbuhan. Jakarta, Grafindo Persada.

Liao, H., H. Wan, J. Shaff, X. Wang, X. Yan, L. V. Kochian. 2006. Phosphorus and Aluminum Interactions in Soybean in Relation to Aluminum Tolerance. Exudation of Specific Organic Acids from Different Regions of the Intact Root System. Plant Physiology, 141: 674 684.

Marschner, P. 2012. Marschner's Mineral Nutrition of Higher Plants. 3rd ed. USA: Elsevier Ltd.

Meena, V. D., M. L. Dotaniya, V. Coumar, S. Rajendiran, Ajay, S. Kundu, and A.S. Rao. 2013. A Case for Silicon Fertilization to Improve Crop Yields in Tropical Soils. Proceedings of the National Academy of Sciences, India Section B: Biological Sciences, 84(3): 505-518.

Panda, S. K. and H. Matsumoto. 2007. Molecular Physiology of Aluminium Toxicity and Tolerance in Plants. The botanical review, 73: 326-347.

Pontigo, S., A. Ribera, L. Gianfreda, M. D. I. L. Mora, M. Nikolic, and P. Cartes. 2015. Silicon in Vascular Plants: Uptake, Transport and its Influence on Mineral Stress under Acidic Conditions. Planta, 242: 23-37.

Ryan, P. R., J. M. Ditomaso, and L. V. Kochian. 1993. Aluminum Toxicity in Roots: An Investigation of Spatial Sensitivity and The Role of The Root Cap. J. Exp. Bot., 44: 437-446.

Silva, S. 2012. Aluminium Toxicity Targets in Plants. Journal of Botany, 2012: 1-8.

Yukamgo, E. and N. W. Yuwono. 2007. Peran silikon sebagai Unsur Bermanfaat pada Tanaman Tebu. Jurnal Ilmu Tanah dan Lingkungan, 7(2): 103-116. 